\title{
Wspótczesny sektor bankowy w warunkach niestabilności finansów publicznych
}

\author{
Ewa Gubernat-Ulatowski*
}

\begin{abstract}
Spowolnienie gospodarcze zazwyczaj kojarzone jest z kryzysem finansów publicznych. Turbulentne otoczenie finansów publicznych wywiera istotny wplyw na swobode prowadzenia działalności bankowej. Oznacza to, że niestabilne otoczenie finansów publicznych oddziatuje na kryzys $w$ sektorze bankowym. Celem opracowania jest wskazanie wzajemnych zależności między kryzysem finansów publicznych a stabilnościa sektora bankowego. W badaniach wykorzystano metodę analizy literatury źródtowej oraz dane empiryczne. Wyniki uzyskane na podstawie przeprowadzonej analizy pozwalaja stwierdzić, że wprowadzone $w$ kilkunastu krajach Europy opodatkowanie banków jest odpowiedzia na hazard moralny banków, ale tė̇ stanowi jeden z istotnych elementów polityki fiskalnej państwa.
\end{abstract}

Słowa kluczowe: sektor bankowy, kryzys finansów publicznych, opodatkowanie banków.

Nadesłany: 06.03.17 | Zaakceptowany do druku: 02.05.17

\section{Contemporary Banking in Conditions of Instability of Public Finances}

The economic slowdown is usually associated with the crisis of public finances. Turbulent environment of public finances has a significant impact on the banking business. This means that the unstable environment affects public finances crisis in the banking sector. The aim of the study is to identify interdependencies between the crisis of public finances and the stability of the banking sector. The study used the method of analysis of the source literature and empirical data. The results, based on the analysis undertaken, lead to the conclusion that it introduced in several European countries, taxation of banks is a response to the moral hazard of banks, but also constitutes one of the essential elements of the fiscal policy of the state.

Keywords: banking sector, the crisis of public finances, taxation of banks.

Submitted: 06.03.17 | Accepted: 02.05.17

JEL: G01, G21, G28

\footnotetext{
* Ewa Gubernat-Ulatowski, dr - Katedra Finansów, Uniwersytet Ekonomiczny we Wrocławiu. Adres do korespondencji: Katedra Finansów, Uniwersytet Ekonomiczny we Wrocławiu, ul. Komandorska 118/120, 53-345 Wrocław; e-mail: ewa.gubernat@ue.wroc.pl.
} 


\section{Wprowadzenie}

Spowolnienie gospodarcze zazwyczaj kojarzone jest z kryzysem finansów publicznych. Turbulentne otoczenie finansów publicznych wywiera natomiast istotny wpływ na swobodę prowadzenia działalności bankowej. Oznacza to, że niestabilne otoczenie finansów publicznych oddziałuje na kryzys w sektorze bankowym. Ponadto procesy te, $\mathrm{z}$ racji doświadczeń ostatnich lat, wzajemnie się przenikają i niejednokrotnie potęgują (Szymański, http). W konsekwencji słabość finansów publicznych kreuje negatywne impulsy dla stabilności sektora bankowego i prowadzenia przezeń działalności bankowej, zaś naruszona równowaga kapitałowa i finansowa banków ogranicza możliwości rozwiązania problemów fiskalnych (Szymański, http). Kryzys finansowy pierwszej dekady XXI wieku spowodował poważne konsekwencje dla budżetów wielu państw, wywołując skutki zarówno bezpośrednie, jak np. dokapitalizowanie banków ze środków budżetowych, jak i te pośrednie $\mathrm{w}$ postaci niższych wpływów z podatków płaconych przez banki. Wobec tego wzajemne oddziaływania między stabilnością sektora bankowego a stanem finansów publicznych stały się głównym impulsem do podjęcia rozważań o sile wzajemnych zależności oraz wskazania konsekwencji kryzysu finansów publicznych dla sektora bankowego. Wzmocnienie stabilności banków jest nie tylko warunkiem koniecznym zrównoważonego rozwoju gospodarczego, lecz także warunkiem zwiększenia bezpieczeństwa finansów publicznych.

\section{Istota wzajemnych relacji między stanem finansów publicznych a sektorem bankowym}

Istotnym elementem spajającym sektor publiczny z sektorem bankowym jest bez wątpienia pomoc publiczna, jaką otrzymują banki. Równocześnie istnieje zależność odwrotna. Niezwykle istotną zmienną wpływu kryzysu finansów publicznych w aspekcie stabilności sektora bankowego są łączne wolumeny, które poszczególne rządy pożyczają od banków krajowych. Kryzys finansów publicznych w dużym stopniu wpływa na sytuację w sektorze bankowym poprzez pryzmat finansowania długu publicznego emisja obligacji skarbowych, których nabywcami często są banki. Wówczas stabilność i efektywność działania banków jest silnie uzależniona od sytuacji w sektorze finansów publicznych. Można zatem wnioskować, że perspektywa rozwoju poszczególnych państw jest zdeterminowana zdolnością banków do sfinansowania długu publicznego. Zależności te zaprezentowano na rysunku 1.

W sytuacji niestabilnych finansów publicznych, zaangażowanie banków w obligacje skarbowe traktowane jest jako ich ekspozycja $w$ instrumenty obarczone wysokim ryzykiem ${ }^{1}$. W następstwie może to obniżać

Rysunek 1. Wzajemne zależności między stanem finansów publicznych a sektorem bankowym

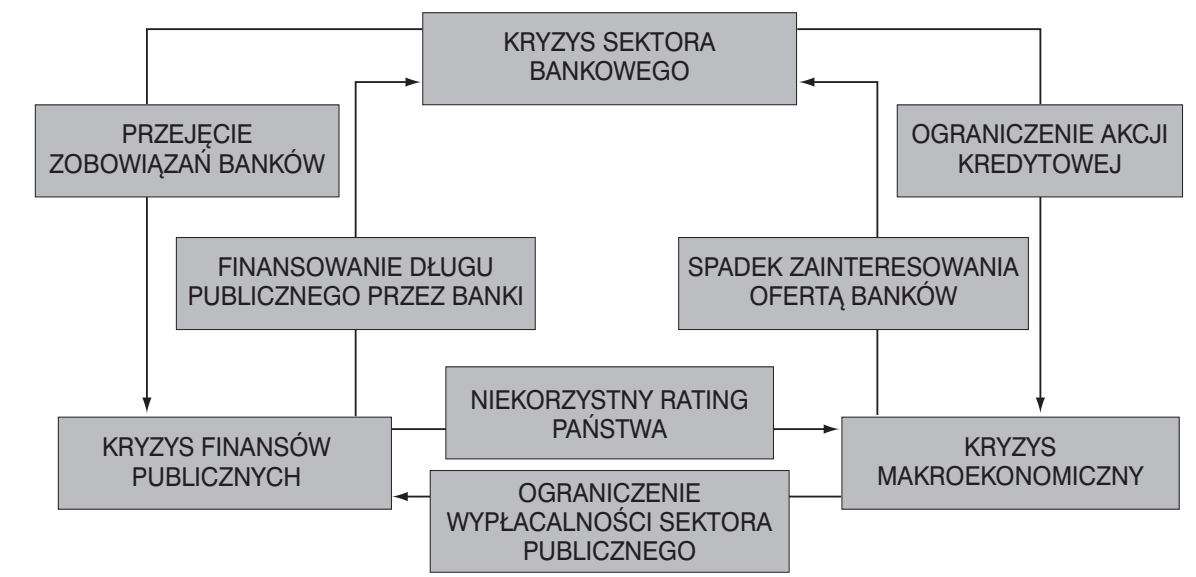

Źródło: J.C. Shambaugh, The Euro's Crises, McDonough School of Business, Georgetown University and NBER, Brooking Papers an Economic Activity, March, 2012, s. 47. 
wiarygodność banków na rynku, szczególnie w sytuacji, kiedy rządy nie są w stanie terminowo obsługiwać zadłużenia. Może to rodzić niebezpieczeństwo, że poprzez pryzmat niskiej jakości portfela kredytowego banki będą postrzegane jako niewiarygodne i niewypłacalne. Jest to tym bardziej istotne, że w gospodarce rynkowej występuje zjawisko niewypłacalności oraz upadłości podmiotów gospodarczych jako naturalny element wolnej konkurencji, co wpływa na mocniejszą pozycję rynkową podmiotów pozostających w danej branży. W przypadku instytucji finansowych, a w szczególności w kontekście banków wyróżniających się szczególnymi cechami, istotnie ryzykowne byłoby określenie, że upadłość jednego $\mathrm{z}$ banków pozytywnie wpłynie na przewagi konkurencyjne jego konkurentów (Szczepańska i in., 2004, s. 7). Inwestorzy na rynku oczekują bowiem, że banki jako instytucje zaufania publicznego wykażą się społeczną odpowiedzialnością ${ }^{2}$, a ich rodzime rzady potrafia realizować właściwa polityke fiskalną. W praktyce może to skutkować zdecydowanym osłabieniem atrakcyjności ofert banków oraz ograniczeniem atrakcyjnych źródeł finansowania szczególnie w odniesieniu do przedsięwzięć inwestycyjnych, beedacych kluczowym czynnikiem długoterminowego wzrostu gospodarczego. W sytuacji spowolnienia gospodarczego i kryzysu makroekonomicznego wysoce prawdopodobne jest obniżenie wiarygodności państwa, a tym samym rozwój kryzysu finansów publicznych ${ }^{3}$. Warto także podkreślić, że obecnie funkcjonuja międzynarodowe grupy bankowe, a utrata zaufania inwestorów może przenosić kryzys na kolejne kraje.

\section{Opodatkowanie sektora bankowego - zagadnienia wybrane}

Sektor finansowy stanowi znaczaca część gospodarki narodowej i globalnej. Główną rolą banków jest bezpieczna alokacja zasobów, a na szczególną uwagę zasługują następujące ich cechy (Szczepańska, Dobrzańska i Zdanowicz, 2015, s. 9-10):

- źródła finansowania banków sa rozproszone, zazwyczaj krótkoterminowe, częstokroć wymagalne na żądanie (np. depozyty), podczas gdy aktywa sa $\mathrm{z}$ reguły długoterminowe, w ich przypadku nie zawsze możliwa jest realiza- cja tzw. szybkiej sprzedaży (np. kredyty), a ich natychmiastowa i wymuszona sprzedaż związana jest z koniecznością poniesienia strat;

- relatywnie niski udział kapitału własnego w relacji do poziomu aktywów definiowany jako wysoka dźwignia finansowa, co w sytuacji wzmożonych wypłat depozytów i wyprzedaży aktywów po zaniżonej cenie negatywnie wpływa na poziom kapitałów banku.

Problematyka nałożenia na banki podatków obecnie jest przedmiotem dyskusji na forum międzynarodowym, a także kluczowym elementem polityki fiskalnej wielu państw europejskich, które uzasadniają to obciążenie następująco:

- w dobie spowolnienia gospodarczego sektor bankowy w wielu krajach został zasilony środkami finansowymi z budżetów krajowych,

- spowolnienie gospodarcze negatywnie wpłynęło na dochody podatkowe uzyskiwane przez rzady, powodujac istotne pogłębianie deficytów budżetowych i wzrost długu publicznego.

Przedmiotem dywagacji są również rozwiązania dotyczące opodatkowania banków, które uwzględniają przede wszystkim następujące aspekty (Miklaszewska, 2004, s. 7):

- zakres podmiotów objętych podatkiem - w obszarze których znalazły się: banki, banki krajowe, banki i firmy inwestycyjne, wszystkie instytucje finansowe, duże instytucje finansowe (ze wskazaną wartością graniczną aktywów), na bazie pojedynczych podmiotów lub grupy kapitałowej,

- charakter opłat/podatków: tj. ex ante, ex post - w przypadku opłat ex ante główna część opłaty jest przeznaczona na stworzenie funduszu restrukturyzacyjnego (stabilizacyjnego), natomiast w przypadku opłaty ex post stanowi ona wpływ budżetowy, pokrywający koszty już poniesione. Stawka opłat powinna być zależna od ryzyka, jakie dana instytucja wnosi do systemu finansowego. Problem ten dotyczy przede wszystkim banków znaczących, czyli takich, które mają istotny wpływ na ryzyko systemowe,

- podstawa: wartość transakcji (wybranych np. pozabilansowych), aktywa, aktywa ważone ryzykiem, depozyty, zobowiązania inne niż depozyty, aktywa zarządzane, dochody operacyjne, zyski, wynagrodzenia lub premie, 
- stawka podatkowa: liniowa, progresywna, liniowa z ograniczeniem kwotowym,

- cel opodatkowania: wpływy budżetowe, fundusz stabilizacyjny/restrukturyzacyjny.

Zakres, podstawa i charakter naliczania podatków mogą być różne. Rozważając kwestię opodatkowania sektora bankowego, należy zatem odpowiedzieć na pytanie, jakie są cele opodatkowania banków i jakie można osiągnąć korzyści. W tym kontekście kluczowe jest zdefiniowanie akceptowalnego społecznie poziomu dochodowości banków. Ponadto należy uwzględnić poprzez pry- zmat opodatkowania banków ryzyko zniszczenia atrakcyjności inwestycyjnej sektora bankowego dla potencjalnych inwestorów i konieczności angażowania środków publicznych w celu zapewnienia bezpieczeństwa systemu finansowego. Konkludując zatem, mamy do czynienia $z$ wyborem miedzy fiskalnym celem opodatkowania banków, głównie krótkookresowym a opodatkowaniem, którego celem jest wzrost stabilności systemu finansowego, oznaczający redukcję ryzyka dla finansów publicznych w długiej perspektywie czasowej (por. tabela 1).

Tabela 1. Cele opodatkowania banków

\begin{tabular}{|c|c|}
\hline \multicolumn{2}{|r|}{ Cele opodatkowania banków } \\
\hline \multicolumn{2}{|r|}{ Horyzont czasowy } \\
\hline $\begin{array}{l}\text { Cele krótkotermi- } \\
\text { nowe (doraźne) }\end{array}$ & $\begin{array}{l}\text { Opodatkowanie banków miałoby służyć zwiększeniu wpływów do budże- } \\
\text { tu państwa oraz przeniesieniu części kosztów spowolnienia gospodarczego } \\
\text { poniesionych przez budżety państw na instytucje finansowe. }\end{array}$ \\
\hline $\begin{array}{l}\text { Cele długotermi- } \\
\text { nowe }\end{array}$ & $\begin{array}{l}\text { Opodatkowanie banków powinno służyć budowaniu specjalnych funduszy, które } \\
\text { mogłyby wspomóc finansowanie restrukturyzacji lub likwidacji banków na wypa- } \\
\text { dek przyszłych kryzysów ekonomicznych. W ten sposób budżety państw nie } \\
\text { byłyby obciążone kosztami pomocy publicznej dla sektora bankowego. Ważnym } \\
\text { aspektem takiej strategii długoterminowej jest dążenie do ograniczenia pokusy } \\
\text { nadużycia, a realizację tego celu miałoby wspomagać zwiększenie zaangażowa- } \\
\text { nia środków prywatnych w kosztach rozwiązywania kryzysów bankowych. }\end{array}$ \\
\hline \multicolumn{2}{|r|}{ Pozostałe cele fiskalne podatku bankowego } \\
\hline $\begin{array}{l}\text { Zwiększenie do- } \\
\text { chodów podatko- } \\
\text { wych państwa }\end{array}$ & $\begin{array}{l}\text { Wzrost dochodów podatkowych budżetu państwa wiąże się z problemami } \\
\text { finansów publicznych w wielu państwach, spowodowanymi głównie (choć } \\
\text { nie wyłącznie) kryzysem finansowym, w tym koniecznością interwencyjnej } \\
\text { pomocy instytucjom finansowym zagrożonym upadłością. }\end{array}$ \\
\hline $\begin{array}{l}\text { Zwiększenie ob- } \\
\text { ciążén podatko- } \\
\text { wych sektora }\end{array}$ & $\begin{array}{l}\text { Opodatkowanie sektora bankowego jest pochodną oceny, że sektor ten w nie- } \\
\text { wielkim stopniu partycypuje w dochodach podatkowych ogółem, natomiast } \\
\text { w istotnym stopniu korzysta z dóbr publicznych. Opodatkowanie odwołuje się } \\
\text { zatem do solidarności i sprawiedliwości społecznej. }\end{array}$ \\
\hline $\begin{array}{l}\text { Nałożenie na sek- } \\
\text { tor finansowy kary } \\
\text { za spowodowanie } \\
\text { kryzysu finanso- } \\
\text { wego }\end{array}$ & $\begin{array}{l}\text { Zważywszy na fakt, że obecny, globalny kryzys finansowy został wywołany } \\
\text { i rozprzestrzeniony przez instytucje finansowe, które nie zachowały podsta- } \\
\text { wowych reguł bezpieczeństwa, rekomendowane są rozwiązania polegające } \\
\text { na obciążeniu banków kosztami interwencji rządowych w formie podatków, } \\
\text { tj. pokrycia fiskalnych kosztów kryzysu. W tym świetle opodatkowanie ban- } \\
\text { ków utożsamiane jest ze zwrotem otrzymanej pomocy publicznej. }\end{array}$ \\
\hline $\begin{array}{l}\text { Konieczność } \\
\text { zwiększenia sta- } \\
\text { bilności sektora } \\
\text { finansowego }\end{array}$ & $\begin{array}{l}\text { Bezpieczeństwo sektora finansowego jest wartością nadrzędną. Konstrukcja } \\
\text { podatku bankowego powinna zatem sprzyjać bezpiecznej polityce banków, ogra- } \\
\text { niczać wolumen transakcji obarczonych wysokim ryzykiem, zapobiegać naduży- } \\
\text { ciom i hazardowi moralnemu w działalności bankowej, a przez to zmniejszyć } \\
\text { zagrożenie wystąpienia kryzysów finansowych w przyszłości. Opodatkowanie } \\
\text { sektora bankowego w kontekście jego stabilności ma na celu budowę dedyko- } \\
\text { wanych funduszy, tj. takich, z których mogłaby zostać sfinansowana restruktu- } \\
\text { ryzacja lub likwidacja banków w przypadku potencjalnych, przyszłych kryzysów. } \\
\text { W tym znaczeniu opodatkowanie banków miałoby korygować zatem negatywne } \\
\text { efekty zewnętrzne związane z prowadzeniem działalności bankowej, a przede } \\
\text { wszystkim zapobiegać nadmiernej ekspozycji na ryzyko systemowe. }\end{array}$ \\
\hline
\end{tabular}

Źródło: opracowanie własne. 
Warto podkreślić, iż obecnie opodatkowanie sektora bankowego, a przede wszystkim skala płaconych przez banki podatków, wciąż budzą wiele kontrowersji. Z jednej strony intensywnie podnoszone sa kwestie, że sektor bankowy ponosi niewspółmiernie niskie obciążenia fiskalne w relacji do jego rozmiarów. Pozostałe opinie odnoszą się do potencjalnych konsekwencji i wpływu na sferę realną i zmniejszenie poziomu atrakcyjności dla inwestorów. Zestawienie argumentów za i przeciw opodatkowaniem sektora bankowego zaprezentowano w tabeli 2 .

Opodatkowanie sektora bankowego winno być zatem zbalansowane, tj. wpływać na wzrost wpływów budżetowych z tytułu podatku, jednak nie powinno służyć tylko ograniczaniu nierównowagi finansów publicznych. Działania dotyczące sfery budżetowej powinny koncentrować się przede wszystkim na redukcji wydatków, a system opodatkowania sektora bankowego powinien skutecznie zapobiegać nadmiernej ekspozycji na ryzyko systemowe i przyszłym kryzysom finansowym.

Banki sa zobowiązane nie tylko w ramach podatku dochodowego, podatku od transakcji finansowych, opłat skarbowych, ale ponoszą także dodatkowe obciążenia quasi-podatkowe. Specyficznym rodzajem dodatkowych obciążeń są między innymi: obowiązkowe rezerwy, składki na fundusze gwarantowania depozytów czy też podatek od środków utrzymywanych w walutach obcych. Innym rodzajem quasi-podatku może być również zalecenie udzielania pożyczek przez banki wskazanym przez państwo sektorom lub nabywania przez te

Tabela 2. Uwarunkowania opodatkowania banków

\begin{tabular}{|l|l|}
\hline \multicolumn{2}{|c|}{ Opodatkowanie sektora bankowego } \\
\hline & $\begin{array}{l}\text { ryzyko systemowe występujące w działalności banków - kryzys jednego banku może szyb- } \\
\text { ko przenieśc się na cały sektor bankowy oraz wywołać istotne konsekwencje dla realnej } \\
\text { sfery gospodarki, }\end{array}$ \\
• wysokie koszty kryzysów bankowych, obciążające wszystkich podatników, \\
- gromadzenie środków ex ante na rozwiązywanie potencjalnych problemów sektora ban- \\
kowego w przyszłości, tj. ograniczenie pomocy publicznej na ratowanie banków,
\end{tabular}

Źródło: opracowanie własne.

Wydział Zarządzania UW ～DOI 10.7172/1733-9758.2017.24.12 
podmioty wskazanych papierów wartościowych. Ta grupa obciążeń sektora bankowego nie znajduje odzwierciedlenia w systemie podatkowym państwa, choć obciążenia te są znacznym źródłem jego dochodów. Zważywszy zatem na współistnienie dodatkowych podatków, możemy stwierdzić, że rzeczywista skala opodatkowania sektora bankowego jest istotnie wyższa.

Konkludując powyższe rozwiązania, należy podkreślić, że zasadniczym celem opodatkowania działalności bankowej jest:

- korygowanie negatywnych efektów zewnętrznych działalności sektora finansowego, w tym przede wszystkim nadmiernej ekspozycji na ryzyko,

- partycypowanie sektora finansowego w kosztach związanych z kryzysem finansowym,

- fundamentalne źródło finansowania realizacji strategii wyjścia rządów ze wsparcia gospodarek.

\section{Podatek bankowy w krajach Unii Europejskiej}

Kryzys finansowy i gospodarczy, którego początek zanotowano w 2008 roku, negatywnie wpłynął na stabilność finansów publicznych w wielu krajach Unii Europejskiej, głównie z uwagi na wydatki zwiazane z działaniami pomocowymi dla sektora finansowego. W istocie kryzys finansowy pochłonął znaczne wolumeny zwiększonych wydatków rządów na pomoc publiczną dedykowaną dla banków, zaś niestabilna sytuacja finansów publicznych determinowała spadek zaufania do banków, posiadających w swoim portfelu inwestycyjnym skarbowe papiery wartościowe. $\mathrm{Na}$ tym etapie wyraźnie widoczne było zjawisko wzajemnego oddziaływania między niestabilnością finansów publicznych a kryzysem bankowym, gdzie zaczęły się wyczerpywać możliwości pomocy finansowej dla banków ze strony rządów. W odpowiedzi na szereg wyżej wskazanych uwarunkowań wiele państw Wspólnoty zaczęło prowadzić działania w kierunku wprowadzenia dodatkowych podatków i opłat od banków. Jako zasadnicze uzasadnienie wskazywano na konieczność finansowej rekompensaty poniesionych kosztów fiskalnych w czasie interwencji rządowych; podkreślano także ogólne potrzeby budżetowe, wynikające $\mathrm{z}$ niższych wpływów podatkowych na skutek spowolnienia gospodarczego. W tym obszarze Komisja Europej- ska zajęła swoje stanowisko, wskazując uzasadnienie potrzeby wprowadzenia podatków od banków (Komunikat Narodowego Banku Polskiego, 2010, s. 6):

- sektor finansowy przyczynił się do powstania kryzysu finansowego, po czym otrzymał wysoką pomoc rządową - zważywszy na wsparcie finansowe, powinien on zatem partycypować w kosztach odbudowania europejskich gospodarek i naprawy finansów publicznych,

- korygujący podatek bankowy mógłby uzupełnić podstawowe środki regulacyjne (w tym podatek bankowy i fundusz naprawczy) opracowane w celu zwiększenia efektywności rynków finansowych i ograniczenia ich zmienności,

- uwzględniając fakt, że sektor finansowy w krajach Wspólnoty jest zwolniony $\mathrm{z}$ podatku od wartości dodanej VAT, to forma opodatkowania banków może zapobiec zbyt niskiemu opodatkowaniu $\mathrm{w}$ porównaniu $\mathrm{z}$ innymi sektorami.

$\mathrm{Z}$ danych przedstawionych $\mathrm{w}$ tabeli 3 wynika, że zasadnicza część funkcjonujących już rozwiązań ma charakter podatków, natomiast pozostałe dotyczą opłat celowych, przeznaczonych na tworzenie funduszy stabilizacyjnych i restrukturyzacyjnych. W kontekście jednomyślności finansów wskazane byłoby, aby fundusze restrukturyzacji banków pozostały odrębne od budżetów krajowych. Wówczas nie będa one zwiększać wpływów budżetowych, a służyć tylko pokryciu kosztów potencjalnych przyszłych kryzysów. Warto zauważyć, że zdecydowana większość krajów Unii, która wprowadziła podatek bankowy, przyjęła jako podstawę opodatkowania pasywa banków z wyłączeniem kapitałów własnych. Pozostałe państwa jako podstawę opodatkowania przyjęły poziom aktywów. Istotne jest, że funkcjonujące obecnie rozwiązania powinny być przedmiotem regularnego przeglądu, który wynika z powiązań i komplementarności opłat z innymi regulacjami dotyczącymi instytucji finansowych, jak również z ewentualnymi podatkami, które mogą zostać w przyszłości nałożone na sektor. Wskazane jest także, aby nakładane na banki dodatkowe opłaty, nie stanowiły zbyt dużego obciążenia dla sektora i by nie wpływały negatywnie na zdolność banków do akumulacji kapitału, ponieważ mogłoby to negatywnie wpłynąć na dostępność akwizycji kredytowej na rynku, a tym samym na perspektywy wzrostu gospodarczego. 


\begin{tabular}{|c|c|c|c|c|c|c|}
\hline Państwo & $\begin{array}{c}\text { Rok } \\
\text { wdrożenia }\end{array}$ & Stawka & $\begin{array}{c}\text { Podstawa } \\
\text { opodatkowania }\end{array}$ & Wyłączenia & $\begin{array}{c}\text { Koszt } \\
\text { podatkowy }\end{array}$ & Wpływy z podatku \\
\hline Austria & 2011 & $\begin{array}{l}0,09 \%-0,11 \%, \text { powyżej } \\
20 \text { mld euro }\end{array}$ & Pasywa & $\begin{array}{l}\text { Kapitał, depozyty ubezpieczeniowe, } \\
\text { niektóre inne zobowiązania, kwota } \\
\text { wolna } 1 \text { mld EUR }\end{array}$ & Tak & $\begin{array}{l}\text { Budżet centralny } \\
\text { Fundusz stabilizacyjny } \\
\text { (lata 2012-2017) }\end{array}$ \\
\hline Belgia & 2012 & $0,035 \%$ & Pasywa & Kapitał, depozyty ubezpieczone & Tak & Fundusz stabilizacyjny \\
\hline Cypr & 2011 & $0,15 \%$ & Pasywa & Opodatkowane tylko depozyty & $\mathrm{Nie}$ & \begin{tabular}{|l} 
Budżet centralny \\
Fundusz stabilizacyjny
\end{tabular} \\
\hline Finlandia & 2013 & $0,125 \%$ & Aktywa (RWA) & $\begin{array}{l}\text { Podstawa opodatkowania to aktywa } \\
\text { ważone ryzykiem }\end{array}$ & $\mathrm{Nie}$ & Budżet centralny \\
\hline Francja & 2011 & $\begin{array}{l}\text { 0,539\%, stopniowa redukcja } \\
\text { do } 0,141 \% \text { w } 2019\end{array}$ & $\begin{array}{l}\text { Minimalny wymóg } \\
\text { kapitałowy }\end{array}$ & Kwota wolna 500 mln eur & Tak & Budżet centralny \\
\hline Łotwa & 2011 & $0,072 \%$ & Pasywa & \begin{tabular}{|l|} 
Kapitał, depozyty objęte systemem \\
gwarantowania, obligacje hipoteczne, \\
zobowiązania podporządkowane
\end{tabular} & Tak & Budżet centralny \\
\hline Holandia & 2012 & $0,022 \%, 0,044 \%$ & Pasywa & $\begin{array}{l}\text { Kapitał, depozyty ubezpieczone, } \\
\text { kwota wolna } 20 \text { mld eur }\end{array}$ & $\mathrm{Nie}$ & Budżet centralny \\
\hline Niemcy & 2011 & $0,02 \%-0,06 \%, 0,0003$ & \begin{tabular}{|l|} 
Pasywa \\
Instrumenty pochodne
\end{tabular} & $\begin{array}{l}\text { Kapitał, depozyty ubezpieczone } \\
\text { Kwota wolna } 200 \text { mln euro }\end{array}$ & $\mathrm{Nie}$ & Fundusz stabilizacyjny \\
\hline Portugalia & 2011 & $\begin{array}{l}0,01 \%-0,085 \% \\
0,001 \%, 0,0003 \%\end{array}$ & $\begin{array}{l}\text { Pasywa } \\
\text { Instrumenty pochodne }\end{array}$ & $\begin{array}{l}\text { Kapitał, depozyty ubezpieczone } \\
\text { Instrumenty pochodne służące } \\
\text { zabezpieczeniu }\end{array}$ & $\mathrm{Nie}$ & Budżet centralny \\
\hline Słowacja & 2012 & $0,4 \%$ & Pasywa & $\begin{array}{l}\text { Kapitał, dług podporzadkowany, } \\
\text { długoterminowe zobowiązania } \\
\text { wewnątrzgrupowe }\end{array}$ & Tak & $\begin{array}{l}\text { Fundusz stabilizacyjny } \\
\text { (cel 1,45\% aktywów } \\
\text { sektora) }\end{array}$ \\
\hline
\end{tabular}


Tabela 3 cd.

\begin{tabular}{|l|c|l|l|l|c|c|}
\hline \multicolumn{1}{|c|}{ Państwo } & $\begin{array}{c}\text { Rok } \\
\text { wdrożenia }\end{array}$ & \multicolumn{1}{|c|}{ Stawka } & $\begin{array}{c}\text { Podstawa } \\
\text { opodatkowania }\end{array}$ & \multicolumn{1}{|c|}{ Wyłączenia } & $\begin{array}{c}\text { Koszt } \\
\text { podatkowy }\end{array}$ & \multicolumn{1}{c|}{ Wplywy z podatku } \\
\hline Szwecja & 2009 & $0,036 \%$ & Pasywa & $\begin{array}{l}\text { Kapitał, zobowiązania } \\
\text { podporządkowane, zobowiązania } \\
\text { wewnątrzgrupowe }\end{array}$ & Tak & Fundusz stabilizacyjny \\
\hline Węgry & 2010 & $\begin{array}{l}0,31 \% \text { powyżej } 50 \text { mld HUF } \\
0,15 \% \text { poniżej } 50 \text { mld HUF }\end{array}$ & Aktywa & $\begin{array}{l}\text { Pożyczki międzybankowe } \\
\text { fożyczki dla przedsiębiorstw }\end{array}$ & Tak & Budżet centralny \\
\hline $\begin{array}{l}\text { Wielka } \\
\text { Brytania }\end{array}$ & 2011 & $\begin{array}{l}0,105 \% \text { dla zobowiązań } \\
\text { długoterminowych }\end{array}$ & Pasywa & $\begin{array}{l}\text { Kapitał, depozyty ubezpieczone } \\
\text { Kwota wolna } 20 \text { mld GBP }\end{array}$ & Nie & Budżet centralny \\
\hline
\end{tabular}

Źródło: opracowanie własne na podstawie OECD, EUROSTAT. 


\section{Pomoc publiczna dla banków w Unii Europejskiej a stabilność sektora bankowego w Polsce}

Głównym czynnikiem łączącym sektor publiczny i bankowy jest pomoc publiczna, którą wykorzystują banki. Skala pomocy finansowej udzielonej przez rządy państw członkowskich sektorowi bankowemu w Unii Europejskiej w latach 2008-2012 stanowiła kwotę 413,2 mld euro, tj. ok. 16,5\% PKB UE (Commission Staff Working Paper, 2012, s. 28). Dominowały wówczas 4 formy pomocy (Crisis Management: Key..., 2010):

- gwarancje rządowe na zobowiązania banków,

- bezpośrednie dokapitalizowanie banków w formie zakupu akcji,

- działania służące poprawie jakości aktywów w formie transferu złych aktywów do specjalnie utworzonych przez rządy podmiotów zarządzających aktywami,

- wsparcie płynnościowe inne niż gwarancje.

Skala udzielonej bankom pomocy publicznej (Koturbowicz, 2011, s. 410) w konsekwencji spowodowała, że wiele rządów stało się większościowymi udziałowcami banków. Skala udzielonej pomocy tylko w okresie 2008-2010 była rozproszona geograficznie. Pomoc koncentrowała się w kilku krajach (por. tabela 4).

Tabela 4. Wykorzystanie pomocy publicznej przez sektor bankowy w wybranych krajach Unii Europejskiej w latach 2008-2010

\begin{tabular}{|l|c|c|}
\hline & Mld EUR & $\begin{array}{c}\text { \% aktywów } \\
\text { sektora bankowego }\end{array}$ \\
\hline $\begin{array}{l}\text { Wielka } \\
\text { Brytania }\end{array}$ & 295 & 3,1 \\
\hline Niemcy & 282 & 3,8 \\
\hline Francja & 141 & 2,0 \\
\hline Irlandia & 117 & 8,9 \\
\hline Hiszpania & 98 & 2,9 \\
\hline Holandia & 95 & 4,3 \\
\hline Grecja & 58 & 11,8 \\
\hline
\end{tabular}

Źródło: opracowanie własne na podstawie The effects of temorary state and rules adopted in the context of the financial and economic crisis, Commission Staff Working Paper, European Commission Competition, 2011, s. 11.
$60 \%$ środków pomocowych zostało skierowane do 3 największych (The effects of temorary state..., 2011, s. 11) systemów finansowych: Wielkiej Brytanii, Francji, Niemiec. Oznacza to, że największe europejskie sektory bankowe wymagały największego wsparcia rządów. Charakterystyczną cechą unijnego sektora bankowego sa transgranicznie grupy bankowe, do których należą ${ }^{4}$ ING, HSBC, Santander, BNP Paribas, Credit Agricole, Unicredit i inne. Posiadają one blisko $70 \%$ aktywów sektora (Liikanen, 2012). Rozbudowana transgraniczna działalność tych banków sprawia, że stają się one duże w relacji do możliwości finansowych budżetów krajów, nawet w przypadku problemów jednego banku. Zatem potencjalna pomoc publiczna może w praktyce być niemożliwa i znacznie przekraczać możliwości finansowe państwa, w którym bank ma siedzibę.

Polski sektor bankowy jest oceniany jako stabilny z uwagi na (Kowalewski i Radło, 2011, s. 9):

- brak wsparcia rządowego w czasie światowego kryzysu - oznacza to, że nie zostały poniesione koszty, które miałyby być zrekompensowane dodatkowymi podatkami,

- niski poziom ubankowienia - mierzony: zarówno relacją aktywów bankowych do $\mathrm{PKB}$, jak i odsetkiem korzystania z usług banku,

- niewspółmierny poziom rozwoju polskiej gospodarki w relacji do pozostałych gospodarek europejskich.

Dotychczasowe działania w polskim sektorze bankowym, mające na celu wzmocnienie jego stabilności, obciążały banki, a nie podatników. Polegały one na: restrykcyjnych wymogach w zakresie adekwatności kapitałowej, konserwatywnej polityce dywidendowej rekomendowanej przez KNF. Pozostałe działania dotyczyły spełniania przez banki dodatkowych wymogów bufora kapitałowego (zgodnie $\mathrm{z}$ art. 128 dyrektywy 2013/36/UE) oraz minimalnych wymogów dotyczacych zobowiązań kwalifikowanych (MREL zgodnie z dyrektywą 2014/59/UE). Wyniki finansowe sektora bankowego wypracowane w 2015 i 2016 roku sa rekordowo dobre, tj. 11405 mln zł za 3q 2015 oraz 11454 za 3q 2016 (po uwzględnieniu polskiego podatku bankowego). Poprawa wyniku finansowego wynikała $\mathrm{z}$ utrzymania dodatniego tempa wzrostu kredytów oraz niewiel- 
kiego wzrostu marży odsetkowej, a także zmniejszenia obciążenia aktywów odpisami z tytułu utraty wartości kredytów na skutek stabilizacji jakości portfela kredytowego (Raport o sytuacji banków, 2016, s. 4).

Banki prowadzące działalność w Polsce to w przede wszystkim spółki córki banków mających siedziby poza granicami kraju. Można zatem oczekiwać, że jeśli spółkę matkę dotyka kryzys finansowy, to problemy te moga zostać przetransferowane do banków - spółek córek. Ostatnie wydarzenia wskazują także na fakt, że trudna sytuacja fiskalna krajów macierzystych spółek matek może powodować, że moga być one zmuszone do ograniczenia skali swojej działalności, w tym również do sprzedaży polskich spółek zależnych. W związku z tym turbulencje występujące w krajach macierzystych spółek matek mogą negatywnie oddziaływać na stabilność sektora bankowego w Polsce.

\section{Podsumowanie}

Sektor publiczny wspiera często sektor bankowy, ale równocześnie istnieje zależność odwrotna. Kluczową determinanta wpływu kryzysu finansów publicznych na stabilność sektora bankowego są kwoty, jakie rządy pożyczają od banków, poziom obowiazkowego obciażenia banków daninami publicznymi. Rozważania podjęte w niniejszej pracy pozwalają stwierdzić, że wpływ kryzysu finansów publicznych na sytuację w sektorze bankowym należy rozpatrywać indywidualnie, w zależności od konkretnych uwarunkowań danego pań stwa. W pracy podjęto rozważania dotyczące nierównowagi finansów publicznych w kontekście stabilności sektora bankowego. Celem autora było wskazanie na wzajemne zależności między sektorem publicznym a bankowym, zdefiniowanie działań, poprzez które kryzys finansów publicznych może oddziaływać na sytuację w sektorze bankowym. Podjęta problematyka pozwala wykazać, że wprowadzone w kilkunastu krajach Europy opodatkowanie banków jest odpowiedzią na hazard moralny banków, ale też stanowi jeden $\mathrm{z}$ istotnych elementów polityki fiskalnej państwa. Omówiona także skala pomocy publicznej państw Europy przemawia za tym, że niezbedne jest wprowadzenie mechanizmów zdecydowanie redukujących skalę angażowania się państwa w działania pomocowe w sektorze bankowym. Za optymalną strukturę pożądanych regulacji w tym zakresie należałoby uznać wzajemne i symetryczne przenikanie się interesu publicznego $\mathrm{w}$ aspekcie jego stabilności oraz prywatnego banków w zakresie uzyskiwanej efektywności z prowadzonej działalności.

\section{Przypisy}

1 Szerzej: Financial Stability Review, European Central Bank, 2011 December, s. 59-74.

2 Współcześnie mówi się o dwóch rodzajach odpowiedzialności biznesu: odnoszącej się do skutków działań (accountability) i polegającej na moralnym zobowiazaniu (responsibility), czyli odpowiedzialności za samo działanie. Szerzej: Korenik (2013).

3 Szerzej: Global Financial Stability Report (2012 April, s. 21-23)

4 Lista G-SiFIs.

\section{Bibliografia}

Commission Staff Working Paper (2012). Update, COM (2012) 778 final. European Commmission.

Crisis Management: Key Policy Issues (2010). Komisja Europejska, 23.09.2010.

Financial Stability Review (2011). European Central Bank, December.

Global Financial Stability Report (2012). International Monetary Fund. April.

Komunikat Narodowego Banku Polskiego (2010) Wybrane aspekty dodatkowego opodatkowania banków w kontekście debaty na forum Unii Europejskiej. Warszawa.

Korenik, D. (2013). Zasady i formy społeczne odpowiedzialnej bankowości. PN Uniwersytetu Ekonomicznego we Wrocławiu, 311, 135-143.

Koturbowicz, T. (2011). Pomoc publiczna UE w warunkach kryzysu gospodarczego. W: J. Kundera (red.), Globalizacja, europejska integracja a kryzys gospodarczy. Wrocław: Prawnicza i Ekonomiczna Biblioteka Cyfrowa.

Kowalewski, O. i Radło, M.J. (2011). Wpływ tymczasowej pomocy publicznej w okresie kryzysu na konkurencję w Unii Europejskiej. Materiaty $i$ Studia NBP, 264.

Liikanen, E. (2012). High-level Expert Group on reforming structure of the EU banking sector. Bruksela.

Miklaszewska, E. (2004). Deregulacja rynków finansowych a zmiany w strategiach banków komercyjnych Kraków: Wydawnictwo Akademii Ekonomicznej w Krakowie. 
Raport o sytuacji banków w okresie 01.-09.2016 (2016). Warszawa: KNF.

Shambaugh, J.C. (2012). The Euro's Crises, McDonough School of Business. Georgetown University and NBER, Brooking Papers an Economic Activity, March.

Szczepańska, O., Dobrzańska, A. i Zdanowicz, B. (2015). Resolution czyli nowe podejście do banków zagrożonych upadtościa. Warszawa: NBP.

Szczepańska, O., Sotomska-Krzysztofik, P., Pawliszyn, M. i Pawlikowski, A. (2004). Instytucjonalne uwarunkowania stabilności finansowej na przykładzie wybranych krajów. Materiaty i Studia, 173, NBP

Szymański, K., Konsekwencje kryzysu zadtużenia w strefie euro dla europejskiego i polskiego sektora bankowego. Warszawa: Instytut Badań nad Gospodarką Rynkową. Pozyskano z: www.kas.de/wf/kas_297751522-8-30.pdf?111219154107 (dostęp 19.01.2017).

The effects of temporary state and rules adopted in the context of the financial and economic crisis (2011). Commission Staff Working Paper, European Commission Competition. 